\title{
Blind Spots
}

\section{ALEXANDRA KROPOTKIN}

From Alexandra Kropotkin, 'Pleasant Memories of Bernard Shaw', New American Mercury, January 1951.

His own judgement of people was usually very shrewd, except where women were concerned. It always seemed to me that the intricacies of the female mind - or perhaps I should say of female character - were beyond his understanding. He was sincerely grieved to see that the famous Beatrice Webb (Mrs Sidney Webb) and I did not get on together. ... Once he complained to me, 'I should have thought that you and Beatrice would hit it off very well.'

'She thinks I'm frivolous,' I replied. 'And I find her so patronising, I have an almost irresistible impulse to talk to her in Cockney slang.'

Mrs Shaw said to me, most unexpectedly, 'Why don't you?' and Shaw looked at his wife in immense astonishment.

Shaw once told me he didn't understand why I got on well with the magnificent Mrs Patrick Campbell, since Mrs Pat was not exactly noted for her sweet attitudes toward other women. 'You don't admire her acting,' Shaw grumbled to me. 'You imitate her quite wickedly. But when I see you together, you both seem to be having a good time.'

'Of course we do,' I answered. 'She is delightfully witty, and I adore being malicious with her.'

Shaw shook his head. He, the great master of malice, simply couldn't understand this feminine twist.

\section{'My Husband' CHARLOTTE SHAW}

From H. F. Wheeler, 'Wife reveals Bernard Shaw', Boston Post, 29 April 1914. Charlotte made a private visit to America with the actress Lena Ashwell in April 